Uşak Üniversitesi Sosyal Bilimler Dergisi

$2014,7 / 3$

\title{
Öğretmenlerin Algıladıkları Yönetici Yeterlik Davranışları ile İlköğretim Kurumları Yöneticilerinin İlişkilerle İlgili Bilişsel Çarpıtmaları Arasındaki İlişki
}

Durdağ $\mathrm{AKAN}^{*}$

İsa YILDIRIM ${ }^{* *}$

Sinan YALÇIN ${ }^{* * *}$

\section{Özet}

$\mathrm{Bu}$ araştırmada, okul yöneticilerinin ilişkilerle ilgili bilişsel çarpıtmaları ile yönetici yeterlik davranışları arasındaki ilişki incelenmiştir. Araştırmada veriler, Hamamcı ve Büyüköztürk'ün (2003) geliştirmiş olduğu "İlişkilerle İlgili Bilişsel Çarpıtmalar" ölçeği ile Şahin'in "ilköğretim okulu müdürleri yeterlikleri" adlı çalışmasına dayalı olarak geliştirilen ölçekten elde edilmiştir. Araştırma örneklemini 50 okul yöneticisi, 200 sinıf öğretmeni olmak üzere toplam 250 eğitimci oluşturmuştur. Araştırmada ölçme araçları kullanılarak okul yöneticilerinin ilişkilerle ilgili bilişsel çarpıtmaları ve öğretmenlerin algıladıkları yönetici yeterlik davranışları verileri toplanmıştır. Bu iki veri gurubu arasındaki ilişkilere spss programında pearson momentler çarpımı korelasyon analizi ve çoklu regresyon analizi ile bakılmıştır. Yapılan analizler sonucunda okul yöneticilerinin "zihin okuma" alt boyutunda ilişkilerle ilgili bilişsel çarpıtmaları ile "öğretim liderliği", "araştırma ve mesleki gelişim", "insan kaynakları yönetimi", "iletişim", "öğrenci işleri", "okul işletmeciliği", "kişilik özellikleri" alt boyutlarında yönetici yeterlik davranışları arasında anlamlı, ters yönde, bir ilişki bulunmuştur.

Anahtar Kelimeler: Bilişsel Çarpıtma, Okul Yöneticisi, İletişim, İnsan İlişkileri.

\footnotetext{
* Yrd. Doç. Dr. Atatürk Üniversitesi K.Karabekir Eğitim Fakültesi, Eğitim Bilimleri Bölümü, durdagiakan@atauni.edu.tr

** Atatürk Üniversitesi Eğitim Bilimleri Enstitüsü Doktora Öğrencisi, isayildirim@outlook.com.tr

*** Atatürk Üniversitesi Eğitim Bilimleri Enstitüsü Doktora Öğrencisi, sinan29@gmail.com
} 


\title{
The Correlation between Teachers' Perceived Managerial Competence Behaviors and Primary School Administrators' Cognitive Distortions about Relationships
}

\begin{abstract}
The present study aims to identify the relationships between primary school managers' interpersonal cognitive distortions and managerial efficacy behaviors. School managers' perceptions of interpersonal cognitive distortions were collected by means of a scale developed by Hamamc1 and Büyüköztürk (2003) and their efficacy behaviors were obtained by means of "Cognitive Distortions Related to Relationships Scale" developed by Şahin (2000). The sample comprised 250 participants, 50 of whom were primary school managers, and 200 of whom were primary school teachers School managers were asked about their interpersonal cognitive distortions and the teachers serving in the same school were asked about school managers' managerial efficacy behaviors and the relationship between these two variables was analyzed on SPSS through Pearson Product Moment Correlation. As a result of the analyses, a negative relationship was found between school managers' interpersonal cognitive distortions in "Mind Reading" and managerial efficacy behaviors in the sub dimensions of Educational Leadership, Research and Professional Development, Human Resources Management, Communication, Student Affairs, School Administration and Personality Traits.
\end{abstract}

Key Words: Cognitive Distortions, Headmaster, Communication, Human Relations.

\section{Giriş}

Yönetimden birinci derecede sorumlu olan yönetici örgütün etkili bir şekilde yönetilmesinde çok önemli bir role sahiptir. Erdoğan'a göre (2000) yönetici belli bir amacı gerçekleştirmek için bir araya gelen insanları hedefe ulaştırmak için ahenk ve iş birliği içinde etkili, verimli olarak yönetmesi beklenen kişidir.

Yönetim ile ilgili davranışlar büyük ölçüde yöneticinin insanın doğasına ilişkin görüşlerine dayanır. İnsanla ilgili kötümser görüş insanın kötü, yırtıcı, rekabetçi, saldırgan, zevk ve güç peşinde koşan, dizginlenmesi ve kontrol edilmesi gereken bir varlık olduğunu savunurken, iyimser görüş insanın iyi, işbirliğine yatkın ve erdemli olduğunu iddia eder (Aydın, 2005, 
Eren, 2006, Şişman, 2011,). Bu düşünce bir ölçüde yönetim kuramlarına da yansımıştır.

Yönetim tarihindeki kuramlar ve bu alanda yapılan çalışmalar incelendiğinde, herhangi bir kurumda yönetici olarak görev yapan bir bireyin, çalışanları ve onlarla olan ilişkilerine dair inanç ve düşüncelerinin olması ve bu inanç ve düşünce temelinde davranışlarına yön vermesi beklenebilir. İnsani bilimler ile ilgilenen araştırmacılar, insanların hem kendileri ve başkalarına dair, hem de dünya ve onun işleyişine dair bir takım gizli inanç ve yargılarının olduğunu kabul etmektedirler. İnsanların çevresiyle etkileşim sonucu oluşan bu inançları, farkında olmadan bütün davranışlarını etkilemekte ve çevresiyle olan ilişkilerine yön vermektedir (Şişman,2011).

Özellikle bireyin insanlarla olan ilişkileri, bu ilişkilerden oluşan inanç ve yargıları kendisini ve ilişkide bulunduğu insanları etkilemektedir. Baucom, Epstein ve Sayers'e göre (1989) insanlarla ilişkilerin nasıl olması gerektiği, ilişkilerden ortaya çıkan olayların sebeplerine dair kişide oluşan düşünceler, ilişkilerle ilgili gelecekte ortaya çıkacak olaylarla ilgili tahminler ve ilişkilerin doğası ile ilgili varsayımlar, kişinin ilişkilerle ilgili inançlarını oluşturmaktadır (Hamamcı, Büyüköztürk, 2003). Bireylerin ilişkilerle ilgili inançlarının mantıklı olması, çarpıtma olmaması, insanlarla ilişkilerini ve kendini olumlu etkiler. İlişkilerle ilgili inançlar mantıktan uzaklaştığı ölçüde kişinin ilişkilerle ilgili bilişsel çarpıtmaları artar. Genel olarak ya toptan kabul edici ya da toptan reddedici düşünme, aşırı genelleme, zihinsel filtreleme, kazanımları ya da pozitif durumları önemsememe, aşırı büyütme yada küçültme (önem derecesini abartma), sürekli olumsuz sonuçlar çıkarma, duygusal düşünme, zorunluluk ifadeleri (meliyim, malıyım ile biten ifadeler), kişiselleştirme, etiketleme-yanlış etiketleme olarak ortaya çıkan ilişkilerle ilgili bilişsel çarpıtmalar (Burns,1980) insanları hem özel hem de iş yaşamlarında etkilemektedir.

Warren, Zgourides, Jones(1989)'in yapmış olduğu bir araştırmada kişilerdeki bilişsel çarpıtmaların, ilişkilerden kaçınmasında önemli bir yordayıcı olduğu anlaşılmıştır. İlişkilerle ilgili bilişsel çarpıtmalar, bireylerin birbirleriyle olan ilişkilerinde işlevsel olmayan duygu ve davranışların ortaya çıkmasına neden olmaktadır(Akın,2010).

Örgüt açısından bakıldığında yöneticinin astları, astlarında aynı düzeydeki çalışma arkadaşları ve üstleriyle ilişkileri ile ilgili bir takım gizli inanç ve düşüncelerinin olabileceği söylenebilir. Örgüt çalışanlarının ilişkilerle ilgili inançlarının işlevsellikten uzaklaştığı oranda örgüt içi iletişim, ekip çalışması gibi ortak beceri gerektiren iş ve eylemlerde aksamalar olacağı varsayılmaktadır. Bu durumun, özellikle insanlar arası ilişkilerin yüz 
yüze ve yoğun olarak yaşandığı eğitim kurumlarında hiçte azımsanmayacak derecede yaşanabileceği düşünülmektedir.

Eğitim kurumlarında görev yapan okul yöneticilerinin, yönetimin iki temel öğesinden biri olan insanlara ilişkin bilişsel çarpıtmaları, onların yönetici yeterlik davranışlarını olumsuz etkileyeceği varsayımına dayalı olarak, bu araştırmada yöneticilerin ilişkilerle ilgili bilişsel çarpıtmaları ile öğretmen algılarına göre yönetici yeterlik davranışları arasındaki ilişkilerin ortaya çıkarılması amaçlanmıştır. Okul yöneticilerinin insan kaynakları yönetimi, iletişim, çevre ilişkileri, öğretimsel liderlik, öğrenci işleri, kişilik özellikleri gibi insana dair bir takım yönetici yeterlik davranışları ile ilişkilerle ilgili bilişsel çarpıtmaları arasındaki ilişkinin niteliğinin bilinmesi, okulların etkili bir şekilde yönetilebilmesi adına bizlere önemli ipuçları vereceği düşünülmektedir.

\section{Kavramsal Çerçeve}

Bilişsel terapi acı, kaygı, depresyon, fobiler gibi bir dizi psikiyatrik rahatsızlıkları tedavi etmek amacıyla kullanılan aktif, yol gösterici, belirli bir zaman süresince uygulanan yapısal bir yaklaşımdır. Bilişsel teknikler bireyin uygun olmayan varsayımlarını, belirli yanlış kanılarını test etme ve betimlemeyi amaçlar. Bireyin bilişleri önceki deneyimlerinden geliştirdiği tutum ve varsayımlara (şemalara) dayanır. Örnek olarak bir kişi bütün deneyimlerini kendisinin yeterli olup olmadığı açısından yorumluyorsa, düşüncesine " herşeyi mükemmel bir şekilde yapmazsam başarısız biriyim" şeması hakim olabilmektedir. Bu gibi çarpıtılmış otomatik düşünceleri ortadan kaldırmayı amaçlayan bilişsel terapi uygulamaları, bireyin psikolojik problemleri hakkında daha gerçekçi, uygun düşünme ve davranmasına ve böylece semptomların azalmasına yardım eder. (Beck;Shaw;Rush, 1987). Akılcı duygusal davranışsal terapide inanç ve inanç sistemleri terimleri, bireyin psikolojik olarak iyi oluşu ve zihinsel sağlığından sorumlu olan insanın bilişsel yönünü temsil eder. İnançlar akılcı duygusal terapinin merkezi açıklayıcı bir yapısıdır (Ellis ve Bernard,2005).

Akılc1-duygusal terapinin temsilcisi olan Ellis'in geliştirmiş olduğu $\mathrm{ABC}$ yaklaşımına göre yaşamımızda bizi harekete geçiren çeşitli olayların duygusal ve davranışsal sonuçları, inanç sistemimiz tarafından kontrol edilmektedir (Nelson-Jones,1982). Bu kuramda A bir olgu, olayın varlığ veya bir kişinin davranışıdır. $C$ bireyin duygusal, davranışsal tepkisi veya izleyen sonuçlardır; tepki sağlıklı veya sağlıksız olabilir. A ( olayın kendisi, harekete geçiren güç) $C^{\prime}$ ye (duygusal, davranışsal sonuç) yol açmaz. C'nin 
oluşumunda asıl rol oynayan süreç kişinin A hakkındaki inancı olan B'dir (Corey,2008). Daha anlaşılır bir şekilde ifade etmek gerekirse bu kurama göre A bizi etkileyen olay, $\mathrm{B}$ bu olaya ilişkin düşüncelerimiz, C ise düşüncelerin etkisiyle oluşan duygu ve davranışlarımızdır (Dökmen,2003). Akılcı duygusal terapi daima bütünsel bir yöntem izleyerek, insanların akılcı olmayan inançlarını akılcı inançlarıyla değiştirme ve böylece duygusal ve davranışsal fonksiyonlarını geliştirmeye yardım etme çabasındadır (Ellis ve Maclaren,2003).

Beck'e göre (1976) bilişsel çarpıtma ya da akılcı olmayan inanç olarak ifade edilen olaylara ilişkin bu düşünceler işlevsel olmayan duygu ve davranışların oluşmasında ve devam ettirilmesinde önemli bir faktördür (Hamamcı ve Büyüköztürk, 2003). Bu yaklaşım insanların hem akılcı ya da "mantıklı", hem de mantık dışı (irrasyonel), ya da hatalı düşünme potansiyeliyle doğduklarını varsayar. Bu yaklaşıma göre mantık dışı inançlarımızı çocukluğumuzda bizim için önemli kişilerden alırız. Ayrıca buna ek olarak kendimize göre mantık dışı dogmalar ve batıl inançlar oluştururuz. Sonrasında, kendimizi alt eden inançlarımızı kendi kendine telkin ve kendini tekrarlama işlemleriyle ve bunlar yararlıymış gibi davranarak destekleyip iyice benimseriz. Bu durum aslında, içimizdeki işlevsel olmayan bizim önceleri benimsediğimiz mantık dışı düşüncelerimizin tekrarıdır (Corey,2008).

Bilişsel terapide duygularımızı ve davranışlarımızı yönlendiren düşüncelerimizi gerçekçi ve akılcı olanlar (mantıklı), gerçekçi ve akılcı olmayanlar (mantıksız) diye iki guruba ayırırız (Dökmen, 2003). Akılıc1duygusal terapinin temsilcisi olan Ellis' e göre mantıklılık; mutluluk ve yaşamı sürdürmek için seçilen amaçlara ulaşmaya yol açan düşünce yollarını içerirken, mantık dışılık ise bunlara ulaşmayı engelleyen ve işi karıştıran düşünceleri içermektedir (Nelson-Jones,1982).Savaşır ve Batur'a göre bilişsel terapi kuramında, bireyin kendisini, çevresini ve geleceğini olumsuz olarak algılamasının önemli etkenlerinden biri de bilgi işlemede yapılan sistematik hatalardır. Bu durumda kişinin düşüncesi bilgiyi işlevsel olmayan yanlı bir biçimde işlemektedir. Beck psikiyatrik hastalıklarda yaşanan duygusal güçlüklerin kaynağının bu düşünme yanlışları yani bilişsel çarpıtmalar olduğunu ifade etmiştir (Kılınç, 2005). Ellis bu tür çarpıtmaları 12 maddede özetlemiştir (Nelson-Jones, 1982).

1-Önemli bulduğun tüm insanlar tarafından her zaman sevilmeli ve beğenilmelisin.

2-Başarıll, yeterli ve yetkin olduğunu ispatlamalısın, en azından bazı önemli konularda yetenekli ve becerili olmalısın. 
3-Olaylar senin istemediğin şekilde geliştiğinde hayat kötü, dehşet verici ve berbattır.

4-Duygusal sıkıntın dış baskılardan kaynaklanmaktadır, sen duygularının denetim altına almada veya depresyondan kaçınmakta, düşmanlık yaşamaktan kendini kurtarmakta pek yeterli değilsin.

5-Sana tehlikeli ve korku verici görünen şeylerle zihnini sürekli meşgul etmeli ve bununla rahatsızlık duymalısın.

6-Hayatın pek çok zorluğu ve sorumluluğu ile yüzleşme yerine kaçınmayı, öz disiplinin getireceği bazı ödülleri toplamaktan daha kolay bir rol olarak seçmeliyim.

7-Geçmişte yaşadığımız önemli olaylar, hayatımızı çok fazla etkilediğinden, bugünkü duygu ve davranışlarımızın belirlenmesinde de rol oynamalıdır.

8-İnsanlar ve her şey olduklarından daha iyi olmalıdırlar; eğer sende yaşamın güçlüklerine ani ve iyi çözümler bulmuyorsan bunu çok kötü ve korkunç bir şey olarak görmelisin.

9-Atalet içinde ve hareketsiz durarak veya pasif bir biçimde, taahhüt altına girmeden, zamanını harcayarak mutluluğa ulaşabilirsin.

10-Son derece düzenli olmalısın, kesinlikle rahat olmamalısın veya güvenebileceğin bazı doğaüstü güçlere gereksinim duy.

11-Kendine değer vermen, kendini kabul etmen, senin değerin, performansının iyi olmasına ve insanların seni beğenmesine bağlıdır.

12-Sana zarar veren insanları genellikle hain ve kötü olarak nitelendir ve bunun için onları en ağır şekilde suçla, lanetle ve cezalandır.

$\mathrm{Bu}$ tür bilişsel hatalar sadece hastalar tarafından değil, sağlıklı insanlarda da görülmektedir (Kılınç, 2005). İnsan ilişkilerinin yoğun olarak yaşandığı eğitim örgütlerindeki yöneticilerin ilişkilerle ilgili bilişsel çarpıtmaları, onların sahip oldukları yönetici yeterlik davranışlarını etkileyip etkilemediği ortaya çıkarılması gereken önemli bir konudur. Çünkü yapılan tüm etkili okul araştırmalarına göre (Brokover ve diğerleri, 1979; Edmonds, 1983; Good ve Brophy, 1986; Fullan, 1985; Lezotte, 1985; Balc1, 1988; Şişman, 2002, Cotton, 2003), etkili bir okulun oluşturulmasında okul yöneticisi çok önemli bir rol oynamaktadır. Okulun başarısı ve sürekliliği, saptanan amaçlara ulaşma derecesine bağlıdır (Taymaz, 2003). Okul yönetimi ve okul toplumu tarafından benimsenip içselleştirilmeyen hiçbir değişimin projesinin amacına ulaştı̆̆ı görülmemiştir (Özden, 2006). Sağlıklı bir örgütsel işleyiş ancak, yönetim alanında yeterli düzeyde eğitilmiş 
ve liderlik rolünü oynayabilecek gerekli bilgi ve becerilerle donanımlı yöneticilerle sağlanabilir (Kaya, 1984).

Dünya'da meydana gelen geniş sosyal, politik, ekonomik ve teknolojik değişmeler okul yöneticisinden beklenen rolleri de değiştirmiştir. Velilerin karar sürecinde söz sahibi olmadığı, okul yöneticilerinin merkezden belirlenen bir programa uymak zorunda olduğu, okul kaynaklarının tahsisinde yöneticilerin rolünün çok az olduğu 1970'lerin okul yönetim anlayışından günümüze doğru baktığımızda okul yöneticilerinden beklenen rollerde büyük değişiklikler yaşandığı görülmektedir. Okul müdürleri artık merkezi olarak kararlaştırılmış bir çerçevede, yerinden yönetimli bir alanda çalışmaktadırlar. Okul yönetiminde, çok kültürlü olan günümüz toplumlarının öğrenci ihtiyaçlarının karşılanması önem kazanmış, yöneticilerden katılımcı, sürekli değişimin ve bu değişime uyumun önemli bir değer halini aldığı bir yönetim anlayışı sergilemeleri beklenmektedir (Balc1, 2011).

Açıkalın'a göre (1998), çağdaş okul yöneticileri; kapsamlı insan bilgisine ulaşmış, etkili iletişim becerilerine sahip, liderlik özellikleri baskın, ana dilini doğru ve güzel kullanabilen, felsefe, matematik, uygarlık tarihi eğitimi görmüş, yabancı dil bilen, iletişim teknolojisine hakim, bilgiyi yöneten, beden ve ruh yönünden sağlıklı, eğitime inanmış insanlardır. Turan (2007), okul yöneticisinin okuldaki değişimin, dönüşümün mimarı olması, okul toplumunun tüm çalışanlarının kişisel ve mesleki gelişimlerine yönelik faaliyetleri düzenlemesi, yeni değerler 1şığında mükemmel bir okul arayışı içinde olması gerektiğini, öğretmenlerin mesleki gelişiminden sorumlu olduğunu, iyi bir öğretim lideri ve iletişimci olması gerektiğini ifade etmiştir. Şahin (2000) yaptığı çalışmada; bir ilköğretim okulu yöneticisinin görevini etkili bir şekilde yerine getirebilmesi için sahip olması gereken yeterlikleri; öğretim liderliği, araştırma ve mesleki gelişim, insan kaynakları yönetimi, okul çevre ilişkileri, iletişim, öğrenci işleri, okul işletmeciliği, kişilik özellikleri boyutlarında toplamıştır. Bu araştırmada okul yöneticisi yeterlikleri yukarıda bahsedilen bu boyutlarıyla ele alınmıştır.

$\mathrm{Bu}$ araştırmanın amacı ilköğretim kurumları yöneticilerinin ilişkilerle ilgili bilişsel çarpıtmaları ile öğretmenlerin algıladıkları yönetici yeterlik davranışları arasındaki ilişkiyi ortaya koymaktır. Bu amaç doğrultusunda aşağıdaki sorulara cevap aranmıştır;

1-İlköğretim kurumları yöneticilerinin ilişkilerle ilgili bilişsel çarpıtmaları alt boyutları ile öğretmenlerinin algıladıkları yönetici yeterlik davranışları alt boyutları arasında anlamlı bir ilişki var mıdır? 
2-i̇lköğretim kurumları yöneticilerinin ilişkilerle ilgili bilişsel çarpıtma genel puanları ile öğretmenlerin algıladıkları yönetici yeterlik davranışları alt boyutları arasında anlamlı bir ilişki var mıdır?

3-İlköğretim kurumları yöneticilerinin ilişkilerle ilgili bilişsel çarpıtmaları öğretmenlerinin algıladıkları yönetici yeterlik davranışlarını yordamakta midır?

\section{Yöntem}

Araştırma geçmişte ya da halen varolan bir durumu varolduğu şekliyle betimlemeyi amaçlayan tarama modelinde tasarlanmıştır (Karasar, 2005). Öğretmenlerin algıladıkları yönetici yeterlik davranışları ile ilköğretim kurumları yöneticilerinin ilişkilerle ilgili bilişsel çarpıtmaları arasındaki ilişkiyi belirlemeye yönelik olarak ilişkisel tarama modeli uygulanmıştır. İlişkisel araştırmalar, iki veya daha fazla değişken arasındaki ilişkileri betimlemek amacıyla yürütülen ve ilişkilerin derinlemesine analiz edildiği araştırmalardır (Tanrıöğen, 2011). Ayrıca ilişkisel araştırmaların, değişkenler arasındaki ilişkilerin açı̆̆a çıkarılmasında, bu ilişkilerin düzeylerinin belirlenmesinde etkili ve bu ilişkilerle ilgili daha üst düzey araştırmaların yapılması için gerekli ipuçlarını sağlayan önemli araştırmalar oldukları söylenebilir (Büyüköztürk ve diğerleri, 2011).

\section{Evren ve Örneklem}

Araştırma evrenini, Erzurum Palandöken, Yakutiye ve Aziziye merkez ilçelerinde, 2011-2012 eğitim öğretim yılında görev yapan ilköğretim okul müdürleri ve öğretmenleri oluşturmaktadır.

Tablo 1: Evren ve örnekleme ilişkin okul yöneticisi ve öğretmen sayıları ve oranları

\begin{tabular}{|c|c|c|c|c|c|c|c|c|}
\hline & \multicolumn{4}{|c|}{ Okul Yöneticisi } & \multicolumn{4}{|c|}{ Öğretmen } \\
\hline & 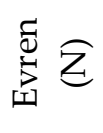 & $\%$ & $\underset{\Xi}{\stackrel{\vec{v}}{\Xi}} \widehat{\Xi}$ & $\%$ & 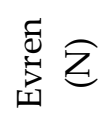 & $\%$ & $\underset{:}{\stackrel{\vec{v}}{\Xi}} \widehat{\Xi}$ & $\%$ \\
\hline Aziziye & 66 & 34 & 16 & 32 & 480 & 13 & 32 & 16 \\
\hline Palandök. & 55 & 28 & 14 & 28 & 1509 & 41 & 78 & 39 \\
\hline Yakutiye & 74 & 38 & 20 & 40 & 1672 & 46 & 90 & 45 \\
\hline TOPLAM & 195 & 100 & 50 & 100 & 3661 & 100 & 200 & 100 \\
\hline
\end{tabular}

Kaynak: http://erzurum.meb.gov.tr/www/dosyalar/icerik/9 
Tablo 1'e baktığımızda Aziziye İlçesi'nde 66 okul yöneticisi evrenin \% 33,8'ini, Palandöken İlçesi'nde 55 okul yöneticisi evrenin \% 28,2'sini, Yakutiye İlçesi'nde 74 okul yöneticisi evrenin \% 38'ini oluşturmaktadır. Aziziye İlçesi'nden 16 okul yöneticisi örneklemin \% 32'sini, Palandöken İlçesi'nden 14 okul yöneticisi örneklemin \% 28'ini, Yakutiye İlçesi'nden 16 okul yöneticisi örneklemin \% 40'ını oluşturmaktadır. Yine tablodan Aziziye İlçesi'nde 480 öğretmen evrenin \% 13,1'ini, Palandöken İlçesi'nde 1509 öğretmen evrenin \% 41,2'sini, Yakutiye İlçesi'nde 1672 öğretmen evrenin \% 45,7'sini oluşturmaktadır. Aziziye İlçesi'nden 32 öğretmen örneklemin \% 16'sını, Palandöken İlçesi'nden 78 öğretmen örneklemin \% 39'unu, Yakutiye İlçesi'nden 90 öğretmen örneklemin \% 45'ini oluşturduğu anlaşılmaktadır.

Araştırma örneklemini ise 50 ilköğretim okulu yöneticisi (okul müdürü) ve farklı branşlardan 200 öğretmen oluşturmuştur. Bu araştırmada tabakalı örnekleme yöntemi kullanılmıştır. Tabakalı örnekleme, evrendeki alt grupların belirlenip bunların evren büyüklüğü içindeki oranlarıyla örneklemde temsil edilmelerini sağlamayı amaçlayan bir örnekleme yöntemidir (Büyüköztürk vd., 2011). Bu yöntemde alt kümeler seçilir. Bunlara tabakalar denir. Bu tabakaların her birini bir evren gibi düşünüp, bunların her birine ait alt kümeler belirlenir. Bu kümelerden tesadüfi örnekleme yöntemi kullanılarak örneklem alınır. Her örneklem de örneklem birimi oranında temsil edilir (Tanrı̈ğgn, 2011).

Okul yöneticilerinin ilişkilerle ilgili bilişsel çarpıtmaları ile ilgili algıları kendilerinden öğrenilmiş, aynı okul yöneticilerinin yönetici yeterlik davranışları ise o okulda çalışan öğretmenlerin algısına göre belirlenmiştir. Okul yöneticilerinden 50, öğretmenlerden 200 anket geri dönmüş ve araştırma örneklemini oluşturmuştur. 
Tablo 2: Örnekleme ait istatistikî veriler

\begin{tabular}{|c|c|c|c|c|}
\hline \multirow{9}{*}{ 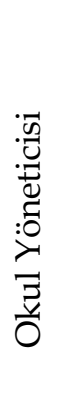 } & \multirow{3}{*}{ Cinsiyet } & & $\mathrm{N}$ & $\%$ \\
\hline & & Kadın & 3 & 6 \\
\hline & & Erkek & 47 & 94 \\
\hline & \multirow{3}{*}{ Öğrenim Durumu } & Ön Lisans & 4 & 8 \\
\hline & & Lisans & 41 & 82 \\
\hline & & Lisans Üstü & 5 & 10 \\
\hline & \multirow{3}{*}{ Mesleki Kıdem } & $6-10 Y_{11}$ & 4 & 8 \\
\hline & & $11-20 Y_{11}$ & 18 & 36 \\
\hline & & 21 Yil ve Üzeri & 28 & 54 \\
\hline \multirow{12}{*}{ 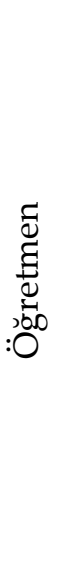 } & \multirow{2}{*}{ Cinsiyet } & Kadın & 83 & 41,5 \\
\hline & & Erkek & 117 & 58,5 \\
\hline & \multirow{3}{*}{ Öğrenim Durumu } & Ön Lisans & 9 & 4,5 \\
\hline & & Lisans & 156 & 78 \\
\hline & & Lisans Üstü & 35 & 17,5 \\
\hline & \multirow{2}{*}{ Branş } & Sınıf Öğretmeni & 108 & 54 \\
\hline & & Branş Öğretmeni & 92 & 46 \\
\hline & \multirow{5}{*}{ Mesleki Kıdem } & 1 Ylldan Az & 2 & 1 \\
\hline & & $1-5 Y_{11}$ & 36 & 18 \\
\hline & & 6-10Yil & 63 & 31,5 \\
\hline & & $11-20 Y_{11}$ & 81 & 40,5 \\
\hline & & 21 Yll ve Üzeri & 18 & 9 \\
\hline
\end{tabular}

Tablo 2 İncelendiğinde okul yöneticilerinin \% 6' sinın bayan, \% 94'ünün erkek, \% 8'inin ön lisans, \%82' sinin lisans, \%10' unun lisansüstü mezunu olduğu, \%8'inin 6-10 yıl, \% 36'sının 11-20 yıl, \% 54'ünün ise 21 yıl ve üzeri mesleki kıdemlerinin olduğu görülmektedir. Aynı tabloda örneklem gurubundaki ögrretmenlerin \% 41,5'inin bayan, \% 58,5'inin erkek, $\%$ 4,5'inin ön lisans, \% 78'inin lisans, \%17,5'inin lisans üstü mezunu olduğu, \% 54'ünün sınıf öğretmeni, \% 46' sının branş öğretmeni olduğu, \% 1'inin 1 yıldan az, \% 18'inin 2-5 yll,\% 31,5'inin 6-10 yıl, \% 40,5'inin $11-20$ yll, \% 9 'unun 21 yıl ve üzeri mesleki kıdeme sahip olduğu görülmektedir.

\section{Veri Toplama Araçları}

Okul yöneticilerinin ilişkilerle ilgili bilişsel çarpıtmaları algıları Hamamcı ve Büyüköztürk'ün(2003) geliştirip, geçerlik ve güvenirlik çalışmasını yapmış olduğu 19 maddelik "İlişkilerle İlgili Bilişsel Çarpıtmalar Ölçeği" kullanılarak elde edilmiştir. İlişkilerle ilgili bilişsel çarpıtmalar ölçeği 
8 maddeden oluşan "Yakınlıktan Kaçınma", 8 maddeden oluşan "Gerçekçi Olmayan İlişki Beklentisi" ve 3 maddeden oluşan "Zihin Okuma" olmak üzere üç alt boyutta geliştirilmiştir. İç tutarlık ve test tekrar test yöntemleri ile güvenirliği incelenen ölçeğin tümü için iç tutarlık katsayısı .67, "Yakınlıktan Kaçınma" alt boyutu için .73, "Gerçekçi Olmayan İlişki Beklentisi" için .66, "Zihin Okuma" alt boyutu için .49 olarak belirlenmiştir. Ölçeğin test tekrar test korelasyon katsayısı ölçeğin tümü için .74 olarak belirlenmiştir. Ölçeğin geçerliğini belirlemek için yapılan çalışmada ölçeğin geneli üzerinden yapılan değerlendirmede diğer ölçeklerle olan korelasyonu pozitif ve anlamlıdır. (Hamamcı \& Büyüköztürk 2003).

İlköğretim okulu müdürlerinin yeterliklerini belirlemek amacıyla Şahin'in (2000) geliştirmiş olduğu ilköğretim okulu müdürleri yeterlikleri adlı çalışmasından yararlanılmıştır. Ölçek Öğretim Liderliği, Araştırma ve Mesleki Gelişim, İnsan Kaynakları Yönetimi, Okul Çevre İlişkileri, İletişim, Öğrenci İşleri, Okul İşletmeciliği, Kişilik Özellikleri olmak üzere 8 boyuttan oluşmaktadır. Ölçeğin boyutlarının Croncbach's Alpha katsayıs1 ,78 ile ,93 aralığında, ölçeğin Croncbach's Alpha katsayısı ise 0,85 olarak bulunmuştur.

\section{Verilerin Analizi}

Öğretmenlerin algıladıkları yönetici yeterlik davranışları ile ilköğretim kurumları yöneticilerinin algıladıkları ilişkilerle ilgili bilişsel çarpıtmaları arasında anlamlı bir ilişkinin olup olmadığını belirlemek için pearson momentler çarpımı korelasyon analizi ve çoklu regresyon analizi kullanılmıştır. Grup ortalama puanları arasındaki farkların test edilmesinde 0.05 anlamlılık düzeyi esas alınmıştır.

\section{Bulgular}

İlköğretim kurumları yöneticilerinin "Yakınlıktan Kaçınma" ilişkilerle ilgili bilişsel çarpıtmaları alt boyutu ile öğretmenlerin algıladıkları yönetici yeterlik davranışları alt boyutları arasındaki ilişkiye ilişkin bulgular; 
Tablo 2: Yöneticilerin "yakınlıktan kaçınma" ilişkilerle ilgili bilişsel çarpıtma alt boyutu ile yönetici yeterlik davranışları alt boyutları arasındaki ilişki

\begin{tabular}{lccc}
\hline & \multicolumn{3}{c}{ Yakınlıktan Kaçınma } \\
\cline { 2 - 4 } & Oearson Correlation & Sig.v(2-t.) & $\mathrm{N}$ \\
\cline { 2 - 4 } Öğretim Liderliği & $-0,85$ & 0,231 & 200 \\
Araş. ve Mes. Gel. & $-0,83$ & 0,245 & 200 \\
İnsan Kayn.Yön. & $-0,112$ & 0,115 & 200 \\
Okul Çevre İlişkileri & $-0,91$ & 0,199 & 200 \\
İletişim & $-0,107$ & 0,131 & 200 \\
Öğgrenci İşleri & $-0,135$ & 0,057 & 200 \\
Okul İşletmeciliği & $-0,115$ & 0,105 & 200 \\
Kişilik Özellikleri & $-0,100$ & 0,158 & 200 \\
\hline
\end{tabular}

İlköğretim okulları müdürlerinin "yakınlıktan kaçınma" ilişkilerle ilgili bilişsel çarpıtma alt boyutu ile yönetici yeterlik davranışları alt boyutları arasında ilişki olup olmadığını belirlemek amacıyla uygulanan pearson momentler çarpımı korelasyon analizi sonucu "yakınlıktan kaçınma" alt boyutu ile "öğrenci işleri" alt boyutu arasında korelasyon değeri -0,135 olarak $p<0,05$ önem düzeyinde anlamlı bulunmuştur. Bu bulgu "yakınlıktan kaçınma" İlişkilerle ilgili bilişsel çarpıtma boyutu ile "öğrenci işleri" yönetici yeterlik davranışları alt boyutu arasında ters yönde bir ilişki olduğunu göstermektedir. Okul yöneticilerinin "yakınlıktan kaçınma" ilişkilerle ilgili bilişsel çarpıtmaları arttıkça "öğrenci işleri" yönetici yeterlik davranışı boyutu puanları azalmıştır. "Yakınlıktan kaçınma" alt boyutu ile diğer alt boyutlar arasında ("öğretim liderliği" $\mathrm{r}=-0,85$, "araştırma ve mesleki gelişim", $r=-0,83$, "insan kaynakları yönetimi" $r=-0,112$, "okul çevre ilişkileri", $r=-0,91$, "iletişim", $r=-0,107$, "okul işletmeciliği", r= $-0,115$, "kişilik özellikleri", $r=-0,1) \quad p>0,05$ önem düzeyinde anlamlı bir ilişki bulunamamıştır.

İlköğretim okulları müdürlerinin algıladıkları "gerçekçi olmayan ilişki beklentisi" ilişkilerle ilgili bilişsel çarpıtmaları alt boyutu ile öğretmenlerin algıladıkları yönetici yeterlik davranışları alt boyutları arasındaki ilişkiye dair bulgular; 
Tablo 3: Yöneticilerin "gerçekçi olmayan ilişki beklentisi" ilişkilerle ilgili bilişsel çarpıtma alt boyutu ile yönetici yeterlik davranışları alt boyutları arasındaki ilişki

\begin{tabular}{lccc}
\hline & \multicolumn{3}{c}{ Gerçekçi Olmay. İliş. Beklen. } \\
& PearsonCor. & Sig.v(2-tailed) & $\mathrm{N}$ \\
\cline { 2 - 4 } Öğretim Liderliği & $-0,002$ & 0,976 & 200 \\
Araş. ve Mes. Gel. & $-0,052$ & 0,466 & 200 \\
İnsan Kayn.Yön. & $-0,052$ & 0,464 & 200 \\
Okul Çevre İlişk. & 0,026 & 0,714 & 200 \\
İletişim & $-0,017$ & 0,813 & 200 \\
Öğrenci İşleri & $-0,044$ & 0,537 & 200 \\
Okul İşletmeciliği & $-0,085$ & 0,233 & 200 \\
Kişilik Özellikleri & 0,020 & 0,776 & 200 \\
\hline
\end{tabular}

İlköğretim okulları müdürlerinin "gerçekçi olmayan ilişki beklentisi" ilişkilerle ilgili bilişsel çarpıtma alt boyutu ile yönetici yeterlik davranışları alt boyutları arasında ilişki olup olmadığını belirlemek amacıyla uygulanan pearson momentler çarpımı korelasyon analizi sonucu "gerçekçi olmayan ilişki beklentisi" alt boyutu ile yönetici yeterlik davranışları alt boyutları ("öğretim liderliği", "araştırma ve mesleki gelişim", "insan kaynakları yönetimi", "okul çevre ilişkileri", "iletişim", "öğrenci işleri", "okul işletmeciliği", "kişilik özellikleri") arasında p>0,05 önem düzeyinde anlamlı bir ilişki bulunamamıştır.

İlköğretim okulları müdürlerinin algıladıkları "zihin okuma" ilişkilerle ilgili bilişsel çarpıtmaları alt boyutu ile öğretmenlerin algıladıkları yönetici yeterlik davranışları alt boyutları arasındaki ilişkiye ilişkin bulgular;

Tablo 4: Yöneticilerin "zihin okuma" ilişkilerle ilgili bilişsel çarpıtma alt boyutu ile yönetici yeterlik davranışları alt boyutları arasındaki ilişki

\begin{tabular}{lccc}
\hline & \multicolumn{3}{c}{ Zihin Okuma } \\
& PearsonCor. & Sig.v(2-ta.) & $\mathrm{N}$ \\
\cline { 2 - 4 } Öğretim Liderliği & $-0,193$ & 0,006 & 200 \\
Araşt. ve Mes.Gel. & $-0,164$ & 0,020 & 200 \\
İnsan Kay.Yön. & $-0,236$ & 0,001 & 200 \\
Okul Çevre İlişk. & $-0,125$ & 0,078 & 200 \\
İletişim & $-0,193$ & 0,006 & 200 \\
Öğrenci İşleri & $-0,177$ & 0,012 & 200 \\
Okul İşletmeciliği & $-0,183$ & 0,009 & 200 \\
Kişilik Özellikleri & $-0,168$ & 0,018 & 200 \\
\hline
\end{tabular}


İlköğretim okulları müdürlerinin "zihin okuma" alt boyutunda ilişkilerle ilgili bilişsel çarpıtmaları ile yönetici yeterlik davranışları alt boyutları arasında ilişki olup olmadığını belirlemek amacıyla uygulanan pearson momentler çarpımı korelasyon analizi sonucu" zihin okuma" alt boyutunda ilişkilerle ilgili bilişsel çarpıtmaları ile "öğretim liderliği" $r=-0,193$, "araştırma ve mesleki gelişim" $\mathrm{r}=-0,164$, "insan kaynakları yönetimi" $\mathrm{r}=-$ 0,236, "iletişim" $r=-0,193$, "öğrenci işleri" $r=-0,177$, "okul işletmeciliği" $r=-$ 0,183, "kişilik özellikleri" $\mathrm{r}=-0,168$ yönetici yeterlik davranışları arasında $\mathrm{p}<$ 0,05 önem düzeyinde anlamlı bir ilişki bulunmuştur. Bu bulgu okul müdürlerin algıladıkları "zihin okuma" alt boyutunda ilişkilerle ilgili bilişsel çarpıtmaları ile yukarıda ifade edilen öğretmenlerin algıladıkları yönetici yeterlik davranış alt boyutları arasında ters yönde bir ilişki olduğunu göstermektedir. Okul müdürlerinin "Zihin Okuma" alt boyutunda ilişkilerle ilgili bilişsel çarpıtmaları arttıkça "öğretim liderliği", "araştırma ve mesleki gelişim", "insan kaynakları yönetimi", "iletişim", "öğrenci işleri", "okul işletmeciliği", "kişilik özellikleri" alt boyutlarında yönetici yeterlik davranış puanları azalmıştır. Okul yöneticilerinin, bir insanın gözünden ne olduğunu anlarım, karşımdaki kişiler ifade etmeseler de ne düşündüğünü anlarım, karşımdaki kişi ben ifade etmesem de ne düşündüğümü anlayabilmelidir gibi zihin okuma alt boyutuna ait ilişkilerle ilgili bilişsel çarpıtmaları arttıkça öğretmenlerin algıladığı okul yöneticisi yeterlik davranışları azalmaktadır. Okul müdürlerinin "zihin okuma" alt boyutunda ilişkilerle ilgili bilişsel çarpitmaları ile "okul çevre ilişkileri" alt boyutunda yönetici yeterlik davranışları arasında $\mathrm{p}>0,05$ önem düzeyinde anlamlı bir ilişki bulunamamıştır.

İlköğretim kurumları yöneticilerinin ilişkilerle ilgili bilişsel çarpıtmaları ile öğretmenlerinin algıladıkları yönetici yeterlik davranışları alt boyutları arasındaki ilişkiye ilişkin bulgular; 
Tablo 5: Yöneticilerin ilişkilerle ilgili bilişsel çarpıtma genel puanları ile yönetici yeterlik davranışları alt boyutları arasındaki ilişki

\begin{tabular}{lccc} 
& İlişkil. İlgili Bilişsel Çarpıtma \\
& Pears.C. & Sig.v(2-ta) & N \\
\hline Öğretim Liderliği & $-0,88$ & 0,216 & 200 \\
Araş. ve Mes. Geliş. & $-0,108$ & 0,129 & 200 \\
İnsan Kay. Yönet. & $-0,140$ & 0,048 & 200 \\
Okul Çevre İlişk. & $-0,060$ & 0,401 & 200 \\
İletişim & $-0,108$ & 0,130 & 200 \\
Öğrenci İşleri & $-0,130$ & 0,067 & 200 \\
Okul İşletmeciliği & $-0,144$ & 0,041 & 200 \\
Kişilik Özellikleri & $-0,078$ & 0,271 & 200 \\
\hline
\end{tabular}

İlköğretim okulları müdürlerinin algıladıkları ilişkilerle ilgili bilişsel çarpıtmaları ile öğretmenlerin algıladıkları yönetici yeterlik davranışları alt boyutları arasında ilişki olup olmadığını belirlemek amacıyla uygulanan pearson momentler çarpımı korelasyon analizi sonucu ilişkilerle ilgili bilişsel çarpıtmalar ile "öğretim liderliği", "araştırma ve mesleki gelişim", "okul çevre ilişkileri", "iletişim", "öğrenci işleri", "kişilik özellikleri" yönetici yeterlik davranışları arasında $\mathrm{p}>0,05$ önem düzeyinde anlamlı bir ilişki bulunamamıștır.

Okul yöneticilerinin algıladıkları bilişsel çarpıtmaları ile "insan kaynakları yönetimi" $r=-0,140$, "okul işletmeciliği" $r=-0,144$ arasında $p<0,05$ önem düzeyinde anlamlı bir ilişki bulunmuştur. $\mathrm{Bu}$ bulgu okul yöneticilerinin algıladıkları ilişkilerle ilgili bilişsel çarpıtmaları ile "insan kaynakları yönetimi" ve "okul işletmeciliği" alt boyutlarında yönetici yeterlik davranış puanları arasında ters yönde bir ilişki olduğunu göstermektedir. Okul yöneticilerin ilişkilerle ilgili bilişsel çarpıtmaları arttıkça "insan kaynakları yönetimi" ve "okul işletmeciliği" alt boyutlarında yönetici yeterlik davranış puanları azalmıştır.

İlköğretim kurumları yöneticilerinin algıladıkları ilişkilerle ilgili bilişsel çarpıtmalarının öğretmenlerin algıladıkları yönetici yeterlik davranışlarını yordama düzeyine ilişkin bulgular: 
Tablo 6: İlişkilerle ilgili bilişsel çarpıtma alt boyutlarının yönetici yeterlik davranışları genel puanlarını yordama düzeyi

\begin{tabular}{lccccccc}
\hline \multicolumn{1}{c}{ Yön.Y. } & $\mathrm{B}$ & $\mathrm{SHB}$ & $\beta$ & $\mathrm{t}$ & $\mathrm{p}$ & İ.r & $\mathrm{K} . \mathrm{r}$ \\
\hline Sabit & 380,9 & 31,2 & & 12,1 &, 00 & & \\
\hline Yak.K. &,- 48 & 1,87 &,- 02 &,- 25 &, 79 &,- 12 &,- 01 \\
\hline Gerç. Olm. İliş.B. & 1,03 & 1,40 &, 05 &, 73 &, 46 &,- 04 &, 05 \\
\hline Zihin Oku. & $-7,54$ & 3,06 &,- 21 & $-2,46$ &, 01 &,- 20 &,- 17 \\
\hline $\mathrm{R}=, 210 \quad \mathrm{R}_{2}=, 044$ & $\mathrm{~F}(3,196)=3,007$ & $\mathrm{P}=, 031$ & & & \\
\hline
\end{tabular}

Yöneticilerin yakınlıktan kaçınma, gerçekçi olmayan ilişki beklentisi, zihin okuma bilişsel çarpıtma alt boyutlarına göre yeterlik davranışlarının yordanmasına ilişkin regresyon analizi sonuçları Tablo 6'da verilmiştir. Yakınlıktan kaçınma, gerçekçi olmayan ilişki beklentisi ve zihin okuma değişkenleri birlikte, yönetici yeterlik davranışları puanları ile düşük düzeyde anlamlı bir ilişki vermektedir. $\mathrm{R}=, 210, \mathrm{R}_{2}=, 044 \mathrm{P}<, 05$ Adı geçen üç değişken birlikte yönetici yeterlik davranışlarındaki toplam varyansın \%4,4'ünü açıklamaktadır. Standardize edilmiş regresyon katsayısına göre, yordayıcı değişkenlerin yönetici yeterlik davranışları üzerindeki önem sırası; zihin okuma, gerçekçi olmayan ilişki beklentisi ve yakınlıktan kaçınmadır. Regresyon katsayılarının anlamlılı̆̆ına ilişkin t-testi sonuçları incelendiğinde ise, sadece zihin okuma değişkeninin yönetici yeterlik davranışları üzerinde anlamlı bir yordayıcı olduğu görülmektedir. Yakınlıktan kaçınma ve gerçekçi olmayan ilişki beklentisi değişkenleri anlamlı bir etkiye sahip değildir.

\section{Sonuç ve Öneriler}

Yöneticilerin insan ilişkileriyle ilgili bilişsel çarpıtmaları ile yöneticilerin öğretmenler tarafından algılanan yeterlik davranışları arasındaki ilişkileri ortaya çıkarmak için yapılan bu araştırmada şu sonuçlara ulaşılmıştır;

Okul yöneticilerinin "yakınlıktan kaçınma" alt boyutunda bilişsel çarpıtmaları ile "öğrenci işleri" alt boyutunda okul yöneticisi yeterlik davranışları arasında anlamlı, ters yönde bir ilişki vardır. Okul yöneticilerinin "yakınlıktan kaçınma" alt boyutunda ilişkilerle ilgili bilişsel çarpıtmaları arttıkça "öğrenci işleri" alt boyutunda yönetici yeterlik davranış puanları azalmaktadır. İnsanlara karşı güvensizlik besleyerek, onlara yakınlaşmaktan kaçınan yöneticilerin öğrenci işleriyle yeterince ilgilenmemesi beklenen bir sonuç olarak düşünülmektedir. 
Okul yöneticilerinin " yakınlıktan kaçınma" alt boyutunda bilişsel çarpıtmaları ile "öğretim liderliği", "araştırma ve mesleki gelişim", "insan kaynakları yönetimi", "okul çevre ilişkileri", "iletişim", "okul işletmeciliği", "kişilik özellikleri" alt boyutlarında yönetici yeterlik davranışları arasında anlamlı bir ilişki bulunamamıştır.

Okul yöneticilerinin "gerçekçi olmayan ilişki beklentisi" alt boyutunda bilişsel çarpıtmaları ile "öğretim liderliği", "araştırma ve mesleki gelişim", "insan kaynakları yönetimi", "okul çevre ilişkileri", "iletişim", "öğrenci işleri", "okul işletmeciliğii", "kişilik özellikleri" alt boyutlarında yönetici yeterlik davranışları arasında anlamlı bir ilişki yoktur. Her ne kadar ilişki anlamlı çıkmasa da sonuçların genellenebilmesi ve bir neticeye varabilmek için aynı konuda yapılacak daha fazla araştırmaya ihtiyaç duyulmaktadir.

Okul yöneticilerinin "zihin okuma" alt boyutunda ilişkilerle ilgili bilişsel çarpıtmaları ile "öğretim liderliği", "araştırma ve mesleki gelişim", "insan kaynakları yönetimi", "iletişim", "öğrenci işleri", "okul işletmeciliği", "kişilik özellikleri" alt boyutlarında yönetici yeterlik davranışları arasında anlamlı, ters yönde bir ilişki vardır. Okul müdürlerinin "zihin okuma" alt boyutunda ilişkilerle ilgili bilişsel çarpıtmaları arttıkça "öğretim liderliği", "araştırma ve mesleki gelişim", "insan kaynakları yönetimi", "iletişim", "öğrenci işleri", "okul işletmeciliğì", "kişilik özellikleri" alt boyutlarında yönetici yeterlik davranış puanları azalmaktadır.

Karşısındaki kişinin konuşmadan zihnini okuyabildiğini düşünen ve karşısındaki kişiden de konuşmadan kendi zihnini okumasını beklediğini düşünen yöneticilerin yeterlik davranışları öğretmenler tarafından diğer yöneticilere göre daha az algılanmaktadır. Bu tür düşüncelere sahip yöneticilerin astlarına karşı etkin dinleme ve benzeri iletişim süreçlerine önem vermeden ön yargılarıyla hareket ettikleri, astlarını anlamadıkları ve uygun insan ilişkileri becerilerini yönetim süreçlerine yansıtamadıkları için böyle algılandıkları düşünülmektedir. Koydemir ve Demir'in (2008) yapmış olduğu araştırmaya göre ilişkilerle ilgili bilişsel çarpıtmalarla utangaçlık arasında anlamlı, aynı yönde bir ilişki vardır. Haferkamp (1994) 74 evli çift ile yapmış olduğu çalışmada ilişkilerle ilgili bilişsel çarpıtmalarla evlilik doyumu arasında ters yönde anlamlı bir ilişki bulunmuştur. Araştırma bulguların yukarıdaki verilerle aynı doğrultuda olduğu söylenilebilir.

Okul müdürlerinin "zihin okuma" alt boyutunda ilişkilerle ilgili bilişsel çarpıtmaları ile "okul çevre ilişkileri" alt boyutunda yönetici yeterlik davranışları arasında anlamlı bir ilişki görülmemektedir.

Okul yöneticilerinin ilişkilerle ilgili bilişsel çarpıtmaları ile "öğretim liderliği", "araştırma ve mesleki gelişim", "okul çevre ilişkileri", "iletişim", 
"öğrenci işleri", "kişilik özellikleri" alt boyutlarında yönetici yeterlik davranışları arasında anlamlı bir ilişki bulunmamaktadır.

Okul yöneticilerinin bilişsel çarpıtmaları ile "insan kaynakları yönetimi", "okul işletmeciliği" alt boyutlarında yönetici yeterlik davranışları arasında ters yönde anlamlı bir ilişki bulunmuştur. Okul yöneticilerin ilişkilerle ilgili bilişsel çarpıtmaları arttıkça "insan kaynakları yönetimi" ve "okul işletmeciliği" alt boyutlarında yönetici yeterlik davranış puanları azalmaktadır. Whisman ve Friedman(1998) çalışmalarında işlevsel olmayan inançlarla algılanan kişilerarası problemler arasında ilişki olduğu sonucuna ulaşmışlardır. Bu durumun yöneticilerin insan kaynakları yönetimini ve okul işletmeciliği yeterliklerini olumsuz etkilediğini düşündürmektedir. Metts ve Cupach (1990) yaptıkları çalışmada ilişkilerle ilgili bilişsel çarpıtmalarla yıkıcı problem çözme tepkileri arasında pozitif ilişki bulmuşlardır. Okul yöneticilerinin ilişkilerle ilgili bilişsel çarpıtmaları ile "insan kaynakları yönetimi" ve "okul işletmeciliğii" alt boyutlarında yönetici yeterlik davranışları arasındaki ilişkinin negatif yönde olması bulguların yukarıdaki araştırma sonucuyla aynı yönde olduğunu göstermektedir.

Okul yöneticilerinin ilişkilerle ilgili bilişsel çarpıtmaları alt boyutları öğretmenlerin algıladıkları yönetici yeterlik davranışları üzerindeki varyansın \% 4,4'ünü açıklamaktadır. Araştırmadan ilköğretim kurumları yöneticilerinin ilişkilerle ilgili bilişsel çarpıtmalarının çok olmasının yönetici yeterlik davranışlarını olumsuz etkilediği sonucuna ulaşılmıştır. Bu konunda yapılan araştırmaların yeterli olmaması bulguların ayrıntılı bir şekilde yorumlanması için bir sınırlılıktır. Bu konuda daha fazla araştırma yapılması ve daha zengin sonuçlara ulaşılması konu hakkında genel bir fikir oluşturmada kolaylık sağlayacaktır. Araştırmada elde edilen bulgulardan okul yöneticilerinin ilişkilerle ilgili bilişsel çarpıtmalarının yöneticilik davranışlarına yansıdı ̆̆ı anlaşılmaktadır. Bu sonuçlara göre yönetici seçiminde yönetici adaylarının ilişkilerle ilgili bilişsel çarpıtmalarının göz önünde bulundurulması, mevcut yöneticilerin ilişkilerle ilgili bilişsel çarpıtmaları konusunda farkındalık oluşturulması ve yönetimi güçlendirme adına okul yöneticilerine gerekli eğitimin verilmesi önerilebilir. 


\section{Kaynakça}

Açıkalın, A. (1998). Okul yöneticiliği (4.Baskı). Ankara. Pegem Yayıncılık

Açıkalın, A., Şişman, M., Turan, S. (2007). Bir insan olarak okul müdürü. Ankara. Pagem A Yayıncilık.

Akın, A. (2010). Self-compassıon and interpersonal cognitıve distortıons- (öz duyarlık ve ilişkilerle ilgili bilişsel çarpıtmalar). Hacettepe Üniversitesi Eğitim Fakültesi Dergisi, Sayı:39, 01-09

Albert E., Catharine M.(1998) Rational Emotive Behavior Therapy A Therapists Guide . California. Impact Publishers

Albert E., Michael E. B. Rational Emotive Behavioral Approaches to Childhood Disorders Theory, Practice and Research. Springer Science+Business Media, Inc. 2006

Aydın, M. (2005). Eğitim yönetimi (7.baskı). Ankara. Hatiboğlu Yayınları

Balc1, A. (2011). Etkili okul, okul geliştirme, kuram uygulama ve araştırma (5.Baskı). Ankara. Pegem Akademi Yayıncılık

Beck, A.T. Shaw B. F., Rush A. J. (1987) Cognitive Therapy of Depression. New York .The Guilford Press.

Brookover, W., Beady, C., Flood, P., Schweitzer, J., \& Wisenbaker, J. (1979). School social systems and student achievement: Schools can make a difference. New York: Praeger.

Burns, D.D. (1981). Feeling Good The New Mood Therapy. New York. Signet Trademark

Buyruk, G. A.(2008). Ergenlerde bilişsel çarpıtmaların, anne baba ilişkilerinin ve bazı kişisel değişkenlerin utangaçlığı yordaması. Yüksek Lisans Tezi. Ankara Üniversitesi Eğitim Bilimleri Enstitüsü.

Büyüköztürk, Ş., Kılıç Çakmak, E., Akgün, Ö. E., Karadeniz, Ş. ve Demirel, F. (2011) Bilimsel araştırma yöntemleri (9. Baskı). Ankara: Pegem Akademi Yayıncilık

Corey, G.(2008). Psikolojik danışma, psikoterapi kuram ve uygulamaları.(T. Ergene, Çeviren). Ankara: Mentis Yayıncılık.

Cotton K. (2003), Principals and Student Achievement (What The Research Says), Association for Supervision and Curriculum Development, Alexandria, Virginia,USA

Dökmen, Ü. (2003). İletişim çatışmaları ve empati (22.Baskı). İstanbul. Sistem Yayıncilik.

Edmonds, R. (1983). Search effective schools resarch: the idenfication and analysis of city school that are instructionally effective for poor children, Michigan State University. 
Erdoğan, İ. (2000). Okul Yönetimi ve Öğretim Liderliği. İstanbul. Sistem Yayıncilik.

Eren, E. (2006). Örgütsel davranış ve yönetim psikolojisi (9.Baskı). İstanbul.Beta Basım Yayım Dağıtım

Fullan, M. (1985). Change processes and strategies at the local level. Elenementary School Journal, 85(3), pp.391-422.

Good, T. L. and Brophy, J. E. (1986). School effects. in m.c. wittrock (ed.),handbook of resarch on teaching, 3rd Ed., New York: Macmillian.

Haferkamp, C. J. (1994). Dysfunctional beliefs, self-monitoring, and marital conflict. Current Psychology, 13(3), 248.

Hamamc1, Z. ve Büyüköztürk, Ş. (2003). İlişkilerle ilgili bilişsel çarpıtmalar ölçeği: ölçeğin geliştirilmesi ve psikometrik özelliklerinin incelenmesi. Çukurova Üniversitesi. Eğitim Fakültesi Dergisi, Sayı 25,15

Kılınç, H. (2005). Ergenlerin yalnızlık düzeyleri ve kişilerarası ilişkilerler ilgili bilişsel çarpıtmaları arasındaki ilişkinin incelenmesi. Yüksek Lisans Tezi. Ankara Üniversitesi. Eğitim Bilimleri Enstitüsü.

Koydemir, S., \& Demir, A. (2008). Shyness and Cognitions: An Examination. of Turkish University Students. Journal Of Psychology, 142(6), 633644.

Mackenzia, D. E. (1983). Resarch of school improvement: an appraisal of some recent trends. Educational Resarcher, Vol.12,No:4,pp.5-16.

Metts, S., \& Cupach, W. R. (1990). The influence of relationship beliefs and problem-solving responses on satisfaction in romantic relationships. Human Communication Research, 17(1), 170.

Özden, Y. (1999). Eğitimde yeni değerler. Pegem Yayınları, Ankara.

Nelson-Jones, R.(1982). The teory and practice of counseling psychology (Danışma Psikolojisi Kuramları).Çev. Akkoyun ve diğ. Qassel Educational Limited.

Şahin, A. E. (2000). İlköğretim okulu müdürlerinin yeterlikleri. Kuram ve Uygulamada Eğitim Yönetimi Dergisi, Sayı 22, 243

Şişman, M. (2011). Örgütler ve kültürler (3.Baskı).Ankara. Pegem Akademi Yayıncilik.

Şişman, M. (2002). Eğitimde mükemmellik arayışı-etkili okullar. Pegem Yayınları, Ankara. 
Tanrı̈ğgn, A. (2011). Bilimsel araştırma yöntemleri (2.Baskı). Ankara: Anı Yayıncilik.

Taymaz, H. (2003). Okul yönetimi (7.Baskı).Ankara. Pagem A Yayıncılık

Warren, R, Zgourides, G. Jones, A. (1989). Cognitive bias and irrational belief as predictors of avoidance. Behavioral Research Therapy, 27 (2), 181188.

Whisman, M.A., \& Friedman, M.A. (1998). Interpersonal problem behaviors associated with dysfunctional attitudes. Cognitive Therapy and Research, 22, 149-160. 